\title{
GENETICS OF INCOMPATIBILITY IN ALSIKE CLOVER, TRIFOLIUM HYBRIDUM
}

\author{
WATKIN WILLIAMS \\ Welsh Plant Breeding Station, Aberystwyth
}

\section{INTRODUCTION}

Received 14.iv.50

Two species of the genus Trifolium-Trifolium pratense and Trifolium repens-have been extensively studied for the purpose of understanding their fertility mechanism. Only a small amount of work has been done in connection with the breeding affinities of $T$. hybridum. The information which is available is confined almost entirely to selffertility, and only one reference (Zhelnina, I932) to artificial crossing has been found in the literature. This work mentions the application of artificial crossing methods, but no tables of results from crosses are given. The present study was made in order to investigate further the precise fertility mechanism in the species, and especially to ascertain whether the cross-compatibility was determined by oppositional factors.

The basic material used in the present study was taken from samples of commercial seed of Canadian or American grown alsike, so that in all cases the original samples probably represent very large breeding populations. From some of the material it was found that the haploid set consists of 8 chromosomes, as found by other workers (Senn, 1938). A diploid type of inheritance can therefore be expected.

Hybridisation was performed by hand, without previous emasculation of the florets, and the method was substantially the same as that described by Williams ( $193 \mathrm{I} b$ ). A minimum number of two heads was used in each cross. Almost all the doubtful crosses were repeated, and in the majority of instances the repeats invariably confirmed the results of the initial tests within the normal limits of variation.

\section{SELF-FERTILITY}

Meehan (1 892) reported alsike clover as being self-fertile, but this guess need not be taken seriously. Other workers--Kirchner (I905), Fruwirth (I906), Witte (1908), Jørgensen (192 I), Williams (1931 $a$ ), and Nilsson-Leissner (1934)-concluded from various tests that the species was highly self-sterile.

A sample of 50 plants used in the present investigation, when tested for spontaneous self-fertility, yielded only 6 seeds from the Io,og6 florets examined-a seed-set of 0.06 per cent. of the florets pollinated. Even when each floret was artificially tripped, thereby 
shattering the pollen grains on to the stigma, only $9^{6}$ seeds were set out of a total of 15,322 florets-a percentage seed-set of 0.63 . These results indicate that $T$. hybridium is highly self-sterile. When tripping is followed immediately by pollination with compatible pollen, it is probable that the number of seeds resulting from selfing is less than reported in the above tests, owing to the quicker growth in the style of the compatible pollen-tubes.

\section{INCOMPATIBILITY}

The oppositional factor hypothesis propounded by East and Mangelsdorf (1925) is well-known and has been found to have a wide application among flowering plants. As far as the writer is aware, approximately I 7 species from phanerogamic orders have given compatibility results which have been interpreted by various authors on the basis of the oppositional factor scheme. These include :-

Nicotiana alata
N. sanderae
Verbascum phoenicium
Veronica syriaca
Cardamine pratensis
Antirrhinum glutinosum

A. segovii Capsella grandiflora

Linaria vulgaris

Prunus spp.

Brassica oleracea

Petunia violacea
$P$. axillaris

Oenothera organensis

Trifolium pratense

T. repens

Melilotus officinalis

Beta vulgaris

It is of particular interest to note that all the above species, with the exception of Beta vulgaris, are typically entomophilous, $B$. vulgaris being the only anemophilous species known to the writer in which an attempt has been made to interpret compatibility on the basis of a multiple allelomorphic series of genes acting oppositionally in the style and the stigma. The investigations on Beta vulgaris (Owen, 1942) were conducted on a very limited range of material, and the postulations need further confirmation before they can be finally accepted. However, it will be interesting to see, as more species are investigated, whether the evolution of the multiple allelomorphic type of sterility is in any way associated with insect pollination. It is quite possible that insect pollination provides a better mechanism for the selective elimination of self pollen than does wind pollination. In many insect-pollinated species, both self- and cross-pollination is impossible without insect visitation, which will invariably ensure that both self and foreign pollen will be present on the stigmas. Opportunity is therefore afforded for selective fertilisation, and mutations which render self pollen ineffective will make the species more flexible and have direct survival value. In wind pollinated plants, on the other hand, it is possible for self pollen to reach the stigma some time before foreign pollen. In some instances, self pollen may be the only kind present, and under such conditions self-pollination can take place frequently in spite of a reduced pollen-tube growth. There is therefore not the same opportunity for the selective elimination of self pollen, and an oppositional type of sterility cannot be easily developed and differentiated. 
Mutation has played an important role in the evolution of the oppositional factor type of sterility. The existence of several allelomorphs at the $\mathrm{S}$ locus has been demonstrated in Nicotiana spp. (East and Yarnell, 1929), Veronica syriaca (Lehmann, 1926), Antirrhinum glutinosum (Gruber, 1932), Trifolium pratense (Williams, I939, 1947a), Oenothera organensis (Emerson, 1939, I940), and Trifolium repens (Atwood, 1944). In Trifolium pratense, Bateman (1947) calculated that the number of alleles operating in the material investigated was 212. This estimate of the number of allelomorphs at a single locus is the largest yet reported.

The modification of the oppositional effect of the sterility factors has been demonstrated in several species. An interesting type of modification apparently caused by inter-allelic competition has recently been reported. Lewis (1947), investigating material of polyploid Oenothera organensis, found that two different alleles in the pollen grain were unable to express the normal inhibiting effect. He suggested that this condition was due to competition between the alleles for basic chemical products, whereby neither gene could acquire the necessary quantity for full expression. In tetraploids which show a high degree of self-compatibility, such as Petunia spp., Pyrus malus, Pyrus communis, and Trifolium repens, inter-allelic competition in the pollen is very strong, but only partial in 0 . organensis where the selfcompatibility resulting from the tetraploid condition is very slight. A similar type of modification was encountered in the present tests.

In addition to showing competition, $\mathrm{S}$ alleles in diploid pollen grains of Oenothera were shown to exhibit dominance. Thus pollen grains of the constitution Sa. $b$, when growing in styles possessing $\mathrm{Sa}$ but not $\mathrm{Sb}$, effected fertilisation but were inhibited in styles carrying $\mathrm{Sb}$ but not Sa. These relationships between two $\mathrm{S}$ alleles show that the efficiency of the individual allelomorphs in effecting sterility is not only due to their nature but also to their interaction in the same genotype.

As a result of investigations on pseudo-fertility in otherwise selfsterile species, certain workers have suggested that minor genes (polygenes) have the effect of modifying the expression of the $\mathrm{S}$ gene in such a way as to weaken or strengthen its action. Lewis (1943), discussing the weakening effect of chromosome doubling on sterility systems, suggests that the $\mathrm{S}$ alleles come under the direct effect of the minor genes, especially in artificial polyploids when the genic balance is upset. In the parent diploid types where the gene system is balanced and the incompatibility reaction is strong, the polygenes are presumed to have little or no effect. Mather (1943) in a discussion on results with Petunia species-crosses suggested that the $\mathrm{S}$ factors simply control the direct working of the compatibility reaction once it is established. They merely behave as " switch" alleles, while the inhibitory reaction itself, as well as its level of expression, are under delicately balanced polygenic control. Mather states, however, that the Petunia crosses 
have not finally established the role of polygenes in connection with incompatibility systems. Furthermore, the experimental material-

\section{TABLE I}

Distribution of genotypes in two $F_{1}$ families of Trifolium hybridum

(The expected figures in each group are given in brackets)

\begin{tabular}{|c|c|c|c|c|c|}
\hline $\begin{array}{c}\text { Family } \\
\text { no. }\end{array}$ & $\begin{array}{c}\text { Group I } \\
\text { No. of plants }\end{array}$ & $\begin{array}{c}\text { Group II } \\
\text { No. of plants }\end{array}$ & $\begin{array}{c}\text { Group III } \\
\text { No. of plants }\end{array}$ & $\begin{array}{c}\text { Group IV } \\
\text { No. of plants }\end{array}$ & $\begin{array}{c}\text { Total } \\
\text { No. of plants }\end{array}$ \\
\hline 51 & 3 & 4 & 3 & 2 & 12 \\
$1_{1}$ & $(3)$ & $(3)$ & $(3)$ & $(3)$ & $(12)$ \\
$(3$ & $(3$ & 2 & $(3)$ & $(12$ \\
\hline
\end{tabular}

$\begin{array}{lcl} & \chi^{2} \text { (corrected for continuity) } \\ \text { Family } 5_{1} & \chi^{2}=0 \cdot 166 & P=0.98 \\ \text { Family } \mathbf{I}_{1} & \chi^{2}=1.66 & \mathrm{P}=0.50-0 \cdot 70\end{array}$

TABLE

Summary of average percentage fertility of all intra- and inter-group crosses of the $F_{\mathbf{1}}$

\begin{tabular}{|c|c|c|c|c|c|c|}
\hline \multirow{2}{*}{7} & \multirow{2}{*}{\multicolumn{2}{|c|}{ 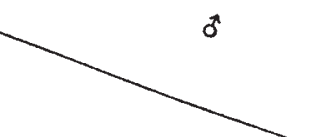 }} & \multicolumn{4}{|c|}{51} \\
\hline & & & Group I & Group II & Group III & Group IV \\
\hline \multirow{5}{*}{ เี } & & Plant nos. & $I, 9, I I$ & $2,5,6,8$ & 3,7, ro & 4,12 \\
\hline & Group I & $I, 9, I I$ & $\begin{array}{l}4.5 \\
(6)\end{array}$ & $\begin{array}{l}149 \\
\text { (12) }\end{array}$ & $\begin{array}{l}150 \\
(9)\end{array}$ & $\begin{array}{l}159 \\
(6)\end{array}$ \\
\hline & Group II & $2,5,6,8$ & $\begin{array}{l}\text { II } \\
\text { (II) }\end{array}$ & $\begin{array}{l}0.83 \\
(12)\end{array}$ & $\begin{array}{l}124 \\
(11)\end{array}$ & $\begin{array}{l}109 \\
(8)\end{array}$ \\
\hline & Group III & $3,7,10$ & $\begin{array}{l}178 \\
(8)\end{array}$ & $\begin{array}{l}\text { I } 7 \mathrm{I} \\
(\mathrm{II})\end{array}$ & $\begin{array}{l}4 \cdot 6 \\
(5)\end{array}$ & $\begin{array}{l}170 \\
(6)\end{array}$ \\
\hline & Group IV & 4,12 & $\begin{array}{l}16 \mathbf{I} \\
(6)\end{array}$ & $\begin{array}{l}187 \\
(7)\end{array}$ & $\begin{array}{l}165 \\
(6)\end{array}$ & $\begin{array}{c}0 \\
\text { (2) }\end{array}$ \\
\hline \multirow{4}{*}{$\Xi$} & Group I & $2,3,7, I I$ & $\cdots$ & $\cdots$ & $\cdots$ & $\cdots$ \\
\hline & Group II & $1,5,8,9,10$ & $\cdots$ & $\cdots$ & $\cdots$ & $\cdots$ \\
\hline & Group III & 12,4 & $\cdots$ & $\cdots$ & $\cdots$ & $\cdots$ \\
\hline & Group IV & 6 & $\cdots$ & $\cdots$ & $\cdots$ & $\cdots$ \\
\hline
\end{tabular}

* No. of crosses from which

$P$. axillaris and $P$. violacea-used in the investigations may have contained accumulated specific differences which might have complicated the results and rendered interpretation more difficult. 
The results presented below give additional evidence on some of these questions, especially as they affect Trifolium hybridium.

\section{(a) Compatibility in two families of Trifolium hybridum resulting from crossing unrelated plants}

On the basis of the oppositional factor hypothesis, each diploid plant should possess two allelomorphs of the $\mathrm{S}$ gene. When two randomly selected plants, each possessing two different allelomorphs at the $\mathrm{S}$ loci, are intercrossed, the resultant $\mathrm{F}_{1}$ consists of 4 groups of inter-fertile, intra-sterile genotypes. Two $F_{1}$ families, Nos. $5_{1}$ and $I_{1}$, each consisting of $I_{2}$ plants, were investigated by means of diallel crossing. In addition, groups of plants isolated from the diallel crosses were further tested by both inter- and intra-group pollinations. A summary of the results obtained is presented in tables I-3.

From table $I$ it is seen that the 4 groups expected in these $F_{1}$ 2

families $5_{1}$ and $I_{1}$. The average percentage pseudo-compatibility of the groups is also given

\begin{tabular}{|c|c|c|c|c|}
\hline \multicolumn{4}{|c|}{$\mathrm{II}_{1}$} & \multirow{3}{*}{$\begin{array}{l}\text { Average pseudo- } \\
\text { self-compatibility } \\
\text { of groups (per cent.) }\end{array}$} \\
\hline Group I & Group II & Group III & Group IV & \\
\hline $2,3,7, I I$ & $1,5,8,9,10$ & 12,4 & 6 & \\
\hline$\cdots$ & $\cdots$ & $\cdots$ & $\cdots$ & $\begin{array}{l}4.3 \\
(3)\end{array}$ \\
\hline$\cdots$ & $\cdots$ & $\cdots$ & $\cdots$ & $\begin{array}{l}0.75 \\
(4)\end{array}$ \\
\hline$\cdots$ & $\cdots$ & $\cdots$ & $\cdots$ & $\begin{array}{c}0 \\
(3)\end{array}$ \\
\hline$\cdots$ & $\cdots$ & $\cdots$ & $\cdots$ & $\begin{array}{l}x \\
(2)\end{array}$ \\
\hline $\begin{array}{l}34 \\
\text { (12) }\end{array}$ & $\begin{array}{l}126 \\
(20)\end{array}$ & $\begin{array}{l}167 \\
\text { (8) }\end{array}$ & $\begin{array}{l}144 \\
(4)\end{array}$ & $\begin{array}{l}2 x \\
(4)\end{array}$ \\
\hline $\begin{array}{l}15 \mathrm{I} \\
(20)\end{array}$ & $\begin{array}{r}43 \\
(20)\end{array}$ & $\begin{array}{l}160 \\
\text { (10) }\end{array}$ & $\begin{array}{l}\text { I } 57 \\
\text { (5) }\end{array}$ & $\begin{array}{l}34 \\
(5)\end{array}$ \\
\hline $\begin{array}{l}154 \\
(8)\end{array}$ & $\begin{array}{l}178 \\
(10)\end{array}$ & $\begin{array}{l}\mathrm{I} \cdot 5 \\
(2)\end{array}$ & $\begin{array}{l}204 \\
(2)\end{array}$ & $\begin{array}{l}I \\
(2)\end{array}$ \\
\hline $\begin{array}{l}\mathrm{I} 48 \\
(4)\end{array}$ & $\begin{array}{l}160 \\
(5)\end{array}$ & $\begin{array}{l}\text { I } 39 \\
(2)\end{array}$ & $\cdots$ & $\begin{array}{c}0 \\
\text { (1) }\end{array}$ \\
\hline
\end{tabular}

fertility was calculated.

families were observed, and that the ratios were in accordance with expectation. Designating the parental genotypes as Sa. $b$ and Sx. $y$, the $\mathrm{F}_{1}$ groups would consist of four genotypes: Sa. $x, \mathrm{Sa} . y, \mathrm{Sb} . x$, 
and Sb. $y$. The seed set obtained in compatible and incompatible matings (table 3 ) shows that the differences between these two types

TABLE 3

Summary of all crosses performed on the two $F_{1}$ families $5_{1}$ and $I_{1}$

\begin{tabular}{|c|c|c|c|}
\hline Types of crosses & No. of florets & No. of seeds & $\begin{array}{l}\text { Seed set } \\
\text { (per cent }\end{array}$ \\
\hline Compatible crosses $\begin{array}{r}51 \\
\mathrm{II}_{1}\end{array}$. & $\begin{array}{r}5,099 \\
10,147\end{array}$ & $\begin{array}{r}7,149 \\
15,203\end{array}$ & $\begin{array}{l}140 \cdot 2 \\
149 \cdot 8\end{array}$ \\
\hline Incompatible crosses $\begin{array}{r}5_{1} \\
\mathrm{I}_{1}\end{array}$ & $\begin{array}{l}1,216 \\
3,970\end{array}$ & $\begin{array}{r}26 \\
1,54^{\circ}\end{array}$ & $\begin{array}{r}2 \cdot I \\
39 \cdot 0\end{array}$ \\
\hline Selfings $\begin{array}{r}51 \\
I_{1}\end{array}$ & $\begin{array}{l}5,097 \\
2,23^{2}\end{array}$ & $\begin{array}{r}8 \\
579\end{array}$ & $\begin{array}{l}0.16 \\
\times 7.9\end{array}$ \\
\hline
\end{tabular}

of crosses were very clearly defined. Family $I_{1}$ showed a significantly higher degree of pseudo-fertility than did family $5_{1}$, but in no instance was pseudo-fertility so high as to obscure group differences in the family.

The chief interest in table 2 lies in the difference in mean seed-set from pseudo-fertility in the intra-group crosses. In groups I and II of family $1 I_{1}$ the average seed-set from pseudo-cross-compatibility was high-34 and 43 per cent. respectively, while the corresponding average for group 1 II was only I.5 per cent. It might be argued, since this latter figure was based on only two crosses, that its significance is doubtful. But since the three plants belonging to groups III and IV in this family were almost completely sterile in both self- and intra-group pollination, while those of the first and second groups showed unmistakenly high pseudo-cross-compatibility, it does suggest that these groups may possess different levels of pseudo-compatibility. Similarly, in family $5_{1}$, groups I and III gave a seed-set from pseudocross-compatibility of 4.5 and 4.6 per cent. respectively, while groups II and IV yielded a seed set of only 0.83 and 0.0 per cent. The " $t$ " test for the means of groups I and III tested against II and IV shows the difference to be significant at the 5 per cent. level $(t=2 \cdot I I 2$, $n=23$ ).

It appears, therefore, that these two families possess two genotypes with high pseudo-cross-compatibility and two with low pseudo-crosscompatibility. The female parent of family I I $_{1}$ exhibited considerable pseudo-self-fertility * and that is the chief reason why this family was selected for investigation. If the genotypes in the cross are denoted as Sa. $b$ o and Sc. $d \vec{o}$, and assuming one of the alleles-say Sa-in the female parent was a weak allele, then the two progeny genotypes

* Plant no. 80, which was the female parent of this family, gave 76 fully developed seeds through self-fertility following artificial manipulation of the heads. 
containing $\mathrm{Sa}$ (Sa. $c$ and Sa. $d$ ) would also presumably exhibit pseudocompatibility, while the other two groups, $\mathrm{Sb} . c$ and $\mathrm{Sb} . d$, would not or only slightly do so. This is one possible interpretation; another possibility will become evident later in connection with the data on $\mathrm{L}_{1}$ families.

\section{(b) Compatibility in $L_{1}$ fomilies of Trifolium hybridum}

The occurrence of pseudo-self-compatibility enables one to observe the behaviour of pollen tubes in styles possessing similar $\mathrm{S}$ alleles to those present in the pollen. Pseudo-compatibility implies either that the inhibitiory reaction is inherently weak, or has become weak as a result of its nuclear and cytoplasmic environment. The possibility of factors delaying the time of production of chemical substances, and thereby retarding the expression of $\mathrm{S}$ alleles, must not be overlooked.

The families $\mathrm{La} / 77$ and $\mathrm{La} / 87$ obtained as a result of pseudo-selfcompatibility were investigated. The distribution of the genotypes present was shown by means of ( $I$ ) using three tester sibs as male parents on all the sister plants, (2) inter-crossing sibs of similar and dissimilar groups on the basis of the results in the first test, and (3) backcrossing to the parent plant. Theoretically, three genotypes were to be expected in each such family-two homozygotes and one heterozygote in the ratio of $I: 1: 2$.

A summary of the distribution of genotypes and of the fertility in the various crosses is given in tables 4 and 5 .

TABLE 4

Distribution of genotypes in two families of Trifolium hybridum obtained as a result of pseudo-self-compatibility

\begin{tabular}{|ccc|c|c|c|}
\hline \multicolumn{2}{|c|}{ Family no. } & $\begin{array}{c}\text { Group I } \\
\text { (homozygous) }\end{array}$ & $\begin{array}{c}\text { Group II } \\
\text { (homozygous) }\end{array}$ & $\begin{array}{c}\text { Group III } \\
\text { (heterozygous) }\end{array}$ \\
\hline $\mathrm{La} / 77$ & $\cdot$ & $\cdot$ & $\cdot$ & 5 & 0 \\
$\mathrm{La} / 87$ & $\cdot$ & $\cdot$ & $\cdot$ & $(2 \cdot 5)^{*}$ & $\begin{array}{c}0 \\
(2 \cdot 5)\end{array}$ \\
\hline
\end{tabular}

* Expectation.

The results presented in table 4 show that in each family there was the complete absence of one of the homozygous genotypes. Unfortunately, the number expected in each family was too small to justify calculation of $\chi^{2}$. Also, probability calculation could not be made on the totals of the two families because the figures obtained depend entirely on to which of the two homozygous groups the homozygous plants in the second family are assigned. It is, however, 
rather remarkable that both families have shown an absence of one of the homozygous classes, particularly since this is accompanied by an excess in the other homozygous group. Since the expected figures are small, these trends must be discussed with caution. One possible cause of the uneven distribution emerges from consideration of the results presented in table 5 .

TABLE 5

Summary of percentage fertility resulting from all the intra- and inter-group crosses made in the $L_{1}$ families La/77 and La/87. The average percentage self-fertility of all the plants in each group is also given

\begin{tabular}{|c|c|c|c|c|c|c|c|}
\hline \multirow{2}{*}{\multicolumn{3}{|c|}{ Genotypes $\longrightarrow$}} & \multicolumn{2}{|c|}{$\mathrm{La} / 77$ ठ } & \multicolumn{2}{|c|}{$\mathrm{La} / 8_{7} \delta$} & \multirow{3}{*}{$\begin{array}{l}\text { Average } \\
\text { pseudo-self- } \\
\text { fertility } \\
\text { of groups } \\
\text { (per cent.) }\end{array}$} \\
\hline & & & Sa. $a$ & Sa. $b$ & Sc. $c$ & Sc. $d$ & \\
\hline & 1 & Plant nos. & $1,3,5,6,7$ & $2,4,8,9,10$ & $1,3,4,6$ & $2,5,7,8$ & \\
\hline \multirow[t]{2}{*}{$\mathrm{La} / 77$ ? } & Sa. $a$ & $1,3,5,6,7$ & $\begin{array}{l}0.322 \\
(23)^{2}\end{array}$ & $\begin{array}{l}167 \\
(8)\end{array}$ & $\cdots$ & $\cdots$ & $\frac{x \cdot 2}{(5)}$ \\
\hline & Sa. $b$ & $2,4,8,9,10$ & $\begin{array}{r}4 \cdot 46 \\
(24)\end{array}$ & $\begin{array}{l}5 \cdot 58 \\
(18)\end{array}$ & $\cdots$ & $\cdots$ & $\begin{array}{l}3.9 \\
(5)\end{array}$ \\
\hline \multirow[t]{2}{*}{$\mathrm{La} / 87$ \& } & Sc. $c$ & $I, 3,4,6$ & $\cdots$ & $\cdots$ & $\begin{array}{c}30 \cdot 90 \\
(18)\end{array}$ & $\begin{array}{l}188 \\
(8)\end{array}$ & $\begin{array}{l}26 \cdot 4 \\
(4)\end{array}$ \\
\hline & Sc. $d$ & $2, .5,7,8$ & $\cdots$ & $\cdots$ & $\begin{array}{c}58 \cdot 17 \\
(14)\end{array}$ & $\begin{array}{l}56 \cdot 92 \\
(22)\end{array}$ & $\begin{array}{l}44^{6} \cdot 6 \\
(4)\end{array}$ \\
\hline
\end{tabular}

* No. of crosses from which fertility was calculated.

The chief point of interest in table 5 is the difference in pseudocompatibility exhibited by the different incompatibility groups. The class $\mathrm{Sa} . a$ in family $\mathrm{La} / 77$ shows high incompatibility. In the crosses involving Sa. $b+{ }^{\circ} \times \mathrm{Sa} . a \sigma^{t}$ the average is about I4 times greater than that for the Sa. $a+\& \times \mathrm{Sa} . a$ o group, and the difference between the two averages is highly significant $(t=2 \cdot 486, \mathrm{P}=0.02-0.01)$. There is no significant difference between the two means $4 \cdot 46$ and $5 \cdot 5^{8}$.

This result indicates that $\mathrm{Sa}$, when present in a homozygote, behaves as a very strong inhibitor of pollen-tubes of like constitution. However, in the Sa. $b+\times$ Sa. $a$ combinations, in which the only difference is the presence of the $\mathrm{Sb}$ allele in the heterozygous female, the inhibitory action of $\mathrm{Sa}$ is rendered considerably less efficient and many more pollen-tubes effect fertilisation. It therefore appears that the presence of the $\mathrm{Sb}$ allele and its products react or compete with the $\mathrm{Sa}$ allele and its products, with the result that the expression of the latter is weakened. If the only comparison present in this data was between the pseudo-self-compatibility of the Sa. $a$ and Sa. $b$ groups, the logical conclusion would have been to attribute differences 
to a weakness in the $\mathrm{Sb}$ allele, and one finds many references in the literature to this kind of weakness in particular alleles. It will be noted, however, that the mean of 18 matings within the Sa. $b$ class, where $\mathrm{Sb}$ was present in 50 per cent. of the pollen, is not significantly different from the mean of the $\mathrm{Sa} . b+\mathrm{q} \times \mathrm{Sa} . a \hat{c}$ crosses where only $\mathrm{Sa}$ pollen was present. If $\mathrm{Sb}$ were considerably weaker than $\mathrm{Sa}$ in this family, a significant difference in the two groups mentioned should result.

In family $\mathrm{La} / 87$ there is no significant difference between the group means of the incompatible matings. However, if the group Sc. $c$ is examined closely (see tables $6-9$ ) it will be noted that only when plant No. 6 was used was any appreciable seed set obtained in crosses within this group. Further, it will be seen from table 7 that of the four plants in the Sc. $c$ class, only No. 6 gave a seed-set of over I.4 per cent. following selfing. The actual percentage pseudo-selfcompatibility in this plant was r 04. The behaviour of plant No. 6 . in this respect resembles plants of the heterozygous group, which exhibited pseudo-self-compatibility as high as 78 per cent., and a pseudo-cross-compatibility of over Ioo per cent. in some crosses. For reasons which are given later, it appears that plant No. 6 could not very well have had any sterility constitution other than Sc. c, but that the genotype Sc. $c$, as expressed in No. 6 , behaved in a very abnormal manner as compared with the other three sister plants of this genotype. The behaviour of this plant suggests that the typical expression of Sc has in some way been changed. This possibility is discussed later.

If, then, all crosses involving plant No. 6 are omitted, the mean compatibility for intra-group crosses involving Sc. $c$ is reduced from $30 \cdot 90$ to $2 \cdot 18$ per cent. The difference between this latter mean $(2 \cdot 18)$ and the mean for the Sc. $d$ o $\times$ Sc. $c \star c$ crosses is significant at the $0 \cdot 00$ I level. This indicates further the weakening effect that can result from interaction between $\mathrm{S}$ alleles in heterozygotes and supports the results obtained with family $\mathrm{La} / 77$. This type of interaction provides another possible explanation for differences in pseudocompatibility shown by the sterility groups in family $I_{1}$, as well as for the absence of one of the two homozygous genotypes mentioned earlier.

\section{(c) The sterility constitution of plant No. 6 in family La/87}

In view of the abnormal behaviour of plant $\mathrm{La} / 8_{7} / 6$, it is proposed to deal with the analysis of this family in detail, so that all the relevant data may be compared. The first step in the analysis involved reciprocal, chain crosses between five sister plants, so that plants known to be of different sterility constitution could be selected as testers for the whole family. The results of these crosses are set out in table 6.

This family proved to be more difficult to analyse, as the high 
percentage pseudo-compatibility expressed by some of the progeny masked the true compatibility relationship of the plants in certain cases. The pseudo-self-compatibility and pseudo-cross-compatibility approached one seed per pod in some instances, and the crosses could then only be separated from the truly compatible ones by careful consideration of the fertility in all the relevant combinations.

TABLE 6

Fertility results of test crosses for the identification of genotypes in family La/8y

\begin{tabular}{|c|c|c|c|c|}
\hline Parents & No. of florets & No. of seeds & $\begin{array}{c}\text { Seed-set } \\
\text { (per cent.) }\end{array}$ & $\begin{array}{l}\text { Proposed } \\
\text { genotypes }\end{array}$ \\
\hline $\begin{array}{l}1 \times 7 \\
7 \times 1 \\
7 \times 5 \\
5 \times 7 \\
5 \times 4 \\
4 \times 5 \\
4 \times 6 \\
6 \times 4\end{array}$ & $\begin{array}{l}55 \\
42 \\
43 \\
39 \\
61 \\
64 \\
66 \\
80\end{array}$ & $\begin{array}{r}82 \\
19 \\
3 \\
5 \\
0 \\
72 \\
19 \\
88\end{array}$ & $\begin{array}{r}249 \\
45 \\
7 \\
23 \\
0 \\
223 \\
28 \\
210\end{array}$ & $\begin{array}{l}\text { Sc. } c \times \text { Sc. } d \\
\text { Sc. } d \times \text { Sc. } c \\
\text { Sc. } d \times \text { Sc. } d \\
\text { Sc. } d \times \text { Sc. } d \\
\text { Sc. } d \times \text { Sc. } c \\
\text { Sc. } c \times \text { Sc. } d \\
\text { Sc. } c \times \text { Sc. } c \text { ? } \\
\text { Sc. } c ? \times \text { Sc. } c\end{array}$ \\
\hline
\end{tabular}

Assuming the constitution of the parent plant to be Sc. $d$, the results set out in table 6 indicate that sibs number 5 and 7 belong to the Sc. $d$ class, while numbers $I$ and 4 appear to be of the genetic constitution Sc.c. The 45 per cent. seed-set obtained in the cross 7 $\times$ I $0^{\star}$ was therefore probably due to pseudo-compatibility. From the test crosses it could not be decided whether the two homozygotes were of the same sterility constitution, but subsequent crosses have shown that both belonged to the Sc. $c$ class. The remaining plant -No. 6-reacted in such a way in the test crosses that its constitution could 'not be definitely decided. It has, however, been assigned the genotype Sc. $c$, based on results which are given in subsequent tables.

As a result of these crosses, three tester plants, Nos. I, 5 and 7 , were selected for crossing as males with the other plants in the family. The results are given in table 7 .

The plants which can be readily assigned their genetic constitution on the basis of their reactions with the tester plants are : Nos. I, 3, and 4 -Sc. $c$ class-and Nos. 5 and 7 -Sc. $d$ class. The remaining plants, Nos. 2, 6 and 8, need further consideration.

Plant No. 2 yielded a low seed-set with all three tester plants, the highest being 102 per cent. with No. 5 as male parent. The pseudo-self-compatibility of this plant amounted to nearly 80 per cent., so that even the 102 per cent. seed-set obtained in the above-mentioned cross was probably the result of pseudo-compatibility. It may be stated that all the tests on pseudo-self-compatibility reported in this family have been calculated from a minimum of six heads involving an average of over 300 florets. All the heads used in such selfings 
where the pseudo-compatibility was relatively high varied only within the limits expected, and not one flower head among the 49 selfed in connection with the analysis of family La/87 gave an unexpected

TABLE 7

Fertility resulting from crossing 8 sister plants of family La/87 with the tester sibs-La/87/I (SC. c), La/87/5 (SC.d) and La/87/7 (SC. d) as male parents. The average pseudoself-fertility of the parent is also given

\begin{tabular}{|c|c|c|c|c|c|}
\hline \multirow{2}{*}{ Parent } & \multicolumn{3}{|c|}{ Tester sibs } & \multirow{2}{*}{$\begin{array}{c}\text { Average } \\
\text { pseudo-self- } \\
\text { fertility } \\
\text { (per cent.) }\end{array}$} & \multirow{2}{*}{$\begin{array}{c}\text { Proposed } \\
\text { genotype of } \\
\text { parent }\end{array}$} \\
\hline & $\begin{array}{c}\mathrm{La} / 87 / \mathrm{r} \\
(\mathrm{Sc} . c)\end{array}$ & $\begin{array}{c}\mathrm{La} / 87 / 5 \\
(\mathrm{Sc} . d)\end{array}$ & $\begin{array}{c}\mathrm{La} / 87 / 7 \\
\text { (Sc. } d)\end{array}$ & & \\
\hline $\begin{array}{cc}\mathrm{La} / 87 / 1 \\
, " & 2 \\
, & 3 \\
, & 4 \\
, " & 5 \\
, & 6 \\
, & 7 \\
, & 8\end{array}$ & $\begin{array}{r}0 \\
71 \\
14 \cdot 3 \\
10 \\
9 \\
121 \\
20 \\
100\end{array}$ & $\begin{array}{r}145 \\
102 \\
56 \\
118 \\
0 \\
222 \\
36 \\
76\end{array}$ & $\begin{array}{r}234 \\
71 \\
165 \\
190 \\
14 \\
184 \\
64 \\
90\end{array}$ & $\begin{array}{r}2 \cdot 3 \\
78 \\
0 \\
0.6 \\
1 \cdot 4 \\
104 \\
64 \\
35\end{array}$ & $\begin{array}{l}\text { Sc. } c \\
\text { Sc. } d \\
\text { Sc. } c \\
\text { Sc. } c \\
\text { Sc. } d \\
\text { Sc. } c \text { ? } \\
\text { Sc. } d \\
\text { Sc. } d \text { ? }\end{array}$ \\
\hline
\end{tabular}

result. The figures given for pseudo-self-compatibility in the plants are therefore considered to be absolutely reliable. In view of the high pseudo-fertility shown by plant No. 2 , its reaction with the testers suggests that it is heterozygous (Sc. $d$ ) for sterility.

The highest percentage pseudo-fertility (I04 per cent.) was expressed by plant No. 6. From its reaction with the Sc. $c$ tester, it is possible that No. 6 was a homozygote (Sc. c), the I2I per cent. seed-set being only another expression of its pseudo-compatibility. In combination with the two Sc. $d$ testers, the seed-set obtained was 83 and 52 per cent. respectively higher than when the Sc. $c$ tester was used. This indicates that at least one of the genes in these heterozygous testers was unmatched in the female. Plant No. 6 has therefore been provisionally classed as an Sc. $c$ type.

The constitution of No. 8 remains doubtful. One is led to believe, however, that all the results of crosses involving No. 8 with the testers are variations of pseudo-compatibility. In the tests for pseudo-selfcompatibility, No. 8 yielded a seed-set of 35 per cent., the six individual heads varying between $I 4^{\circ} \mathrm{I}$ and $74 \cdot 5$. This wide range of pseudoself-compatibility indicates that the three test crosses were pseudocompatible and that plant No. 8 was of the constitution Sc. $d$.

This is further substantiated by inter- and intra-group tests summarised in tables 8 and 9 .

The intra-group crosses in table 8 demonstrate clearly that Nos. 1, 3 and 4 belong to the same sterility group. Plant No. 6 in reciprocal crosses with plant No. I gave 84 per cent. seed-setting, but it will be noted that this seed-set amounts to less than half the fertility 
expressed in six truly compatible crosses where No. 6 was involved. This, together with the high pseudo-self-compatibility exhibited by No. 6, strongly suggests that Nos. I and 6 were of the same constitution, and therefore confirms the tentative sterility genotype previously assigned to plant No. 6 .

TAB LE 8

Fertility results of intra-group crosses among $L_{1}$ plants of family La/87

\begin{tabular}{|c|c|c|c|c|c|}
\hline Parents & $\begin{array}{l}\text { No. of } \\
\text { florets }\end{array}$ & $\begin{array}{l}\text { No. of } \\
\text { seeds }\end{array}$ & $\begin{array}{l}\text { Percentage } \\
\text { seed-set }\end{array}$ & $\begin{array}{l}\text { Fertility } \\
\text { of parent * } \\
\text { (per cent.) }\end{array}$ & Genotypes \\
\hline $\begin{array}{l}1 \times 3 \\
3 \times 1 \\
1 \times 4 \\
4 \times 1 \\
3 \times 4 \\
4 \times 3 \\
1 \times 6 \\
6 \times 1\end{array}$ & $\begin{array}{r}103 \\
103 \\
102 \\
96 \\
94 \\
109 \\
197 \\
176\end{array}$ & $\begin{array}{r}0 \\
0 \\
0 \\
0 \\
0 \\
0 \\
170 \\
142\end{array}$ & 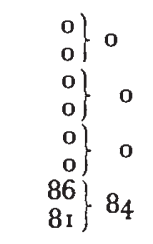 & $\begin{array}{r}206(6) \\
\times 39(3) \\
206(6) \\
\ldots \ldots(3) \\
\times 39(3) \\
266(6) \\
x 9 x(6)\end{array}$ & 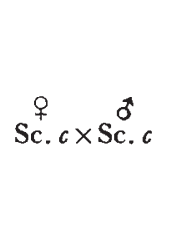 \\
\hline Total & 980 & 312 & $3^{2}$ & & \\
\hline $\begin{array}{l}2 \times 8 \\
8 \times 2 \\
5 \times 7 \\
7 \times 5 \\
7 \times 8 \\
8 \times 7 \\
8 \times 5 \\
5 \times 8\end{array}$ & $\begin{array}{r}100 \\
109 \\
294 \\
308 \\
100 \\
103 \\
99 \\
101\end{array}$ & $\begin{array}{r}\text { ro8 } \\
88 \\
\text { r } 95 \\
319 \\
75 \\
58 \\
68 \\
43\end{array}$ & 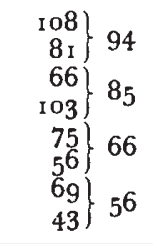 & $\begin{array}{l}89(5) \\
79(8) \\
27(8) \\
75(7) \\
79(8) \\
27(8)\end{array}$ & $\stackrel{+}{\stackrel{+}{2} d \times \text { Sc. }^{\star} d}$ \\
\hline Total & 1214 & 954 & 79 & & \\
\hline
\end{tabular}

* In column 5 the figures for the Sc. $c$ $\$ \times S c . c \delta^{*}$ crosses refer to averages of compatible matings, while those for the Sc. $d q \times$ Sc. $d \delta$ crosses refer to averages of incompatible matings. The figures in brackets in this column refer to the number of crosses from which the average was calculated.

With regard to the crosses between plants of the heterozygous group, it is fairly evident that the results obtained were expressions of very high pseudo-compatibility. This conclusion is based on (I) the high pseudo-self-compatibility shown by the group-ranging from $\mathrm{I} \cdot 4$ to 78 per cent. ; (2) the similarity in the fertility obtained in the crosses and the average figure for pseudo-cross-compatibility shown by the female parents; and (3) the fact that the highest percentage fertility ( 108 per cent.) in the matings was less than $5^{\circ}$ per cent. of the highest results from fully compatible crosses, while the average figure (79 per cent.) for the group was only 40 per cent. of the average in all the compatible crosses in the family.

From table 9 it will be noted that excellent fertility resulted from all the Sc. $c$ 옹 $\times$ sc. $d$ crosses, while the reciprocal crosses were lower in fertility by more than 50 per cent., as is to be expected.

The behaviour of sister plant No. 6 in this family is interesting because, on the basis of the results, it appears to be of the Sc. $c$ 
constitution, and yet its behaviour when selfed and when crossed with other plants of the same sterility constitution is precisely the same as that expressed by Sc. $d$ plants. In crosses of the type Sc. $c q \times$ Sc. $d \sigma$, however, No. 6 behaved as a normal Sc. $c$ and expressed full fertility, so that the difference which exists between the Sc. $c$ genotype in this plant, as compared with the other three sister plants of the

TABLE 9

Fertility results of inter-group crosses among $L_{1}$ plants of family La/87

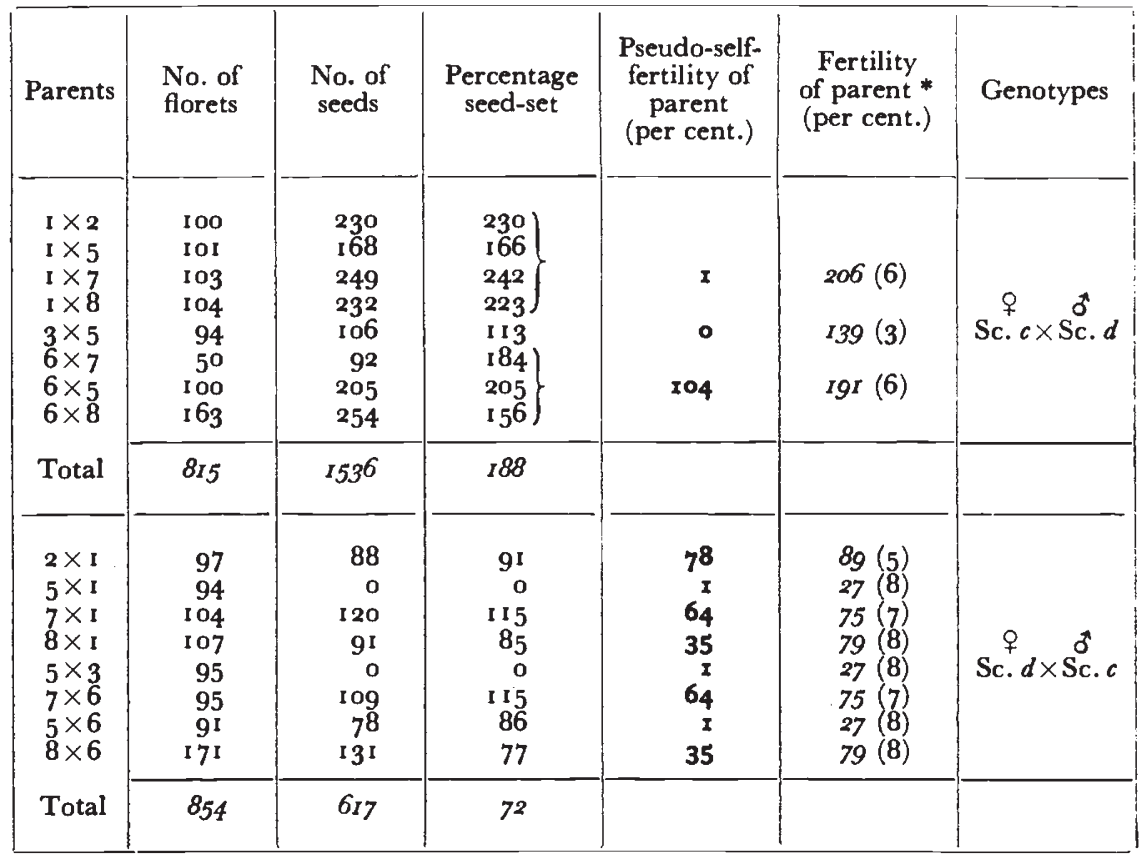

* In column 6 the figures for the Sc. $c q \times \mathrm{Sc} . d \delta$ crosses refer to averages of compatible matings, while those for the Sc. $d+\$ \times S c . c \delta$ crosses refer to averages of incompatible matings. The figures in brackets in this column refer to the number of crosses from which the average was calculated.

same constitution, is such that it affects only pseudo-compatibility. In addition, it must be noted that this difference in pseudocompatibility is of a similar order to that which exists between the Sc. $c$ sibs and the Sc. $d$ group. Possible explanations for this behaviour are presented in the discussion.

(d) Compatibility in three families resulting from crossing unrelated plants with plants homozygous for the $S$ factors

Twelve randomly selected plants-Nos. 9I/I-9I/ I 2-were crossed as females with $\mathrm{La} / 77 / 6$, which had been shown to be homozygous for the sterility factors. Three of the resulting families, Nos. 5021, $509_{1}$, and $5 \mathrm{ro}_{1}$ consisting of 26,28 and 27 plants respectively, were 
chosen for a detailed study on the segregation of sterility factors. On the basis of the oppositional factor hypothesis, not more than two sterility genotypes should appear as a result of such matings.

For the analysis of the progeny, six tester sibs from each family were crossed as male parents with all their sister plants, and an average of approximately 100 florets was pollinated in each cross.

The summary of the analysis is set out in tables Io and II.

TABLE IO

Summary of the analysis of sterility genotypes in three families, resulting from crossing plants of the constitution $S x$ y $q \times S a$ a o

\begin{tabular}{|c|c|c|c|c|}
\hline \multirow{2}{*}{ Family no. } & \multicolumn{2}{|c|}{ Genotypes } & \multirow{2}{*}{$x^{2}$} & \multirow{2}{*}{$P$} \\
\hline & Sa. $x^{*}$ & Sa. $y$ & & \\
\hline 5021 & I3 & I3 & $0 \cdot 00$ & $1 \cdot 0$ \\
\hline $509 x$ & I3 & I 5 & $0 \cdot 14.3$ & $0 \cdot 70$ \\
\hline $5 \mathrm{IO}_{1}$ & I 6 & I I & 0.926 & $0.50-0.30$ \\
\hline
\end{tabular}

* Sx and Sy represent the two unidentified alleles recovered from each of the three ㅇ parents.

TABLE II

Frequency distribution of percentage seed-set in the incompatible crosses in families $502_{1}, 509_{1}$ and $510_{1}$

\begin{tabular}{|c|c|c|c|c|c|c|c|c|c|c|c|c|c|}
\hline \multirow{2}{*}{ Family } & \multirow{2}{*}{ Genotypes } & \multicolumn{11}{|c|}{ Percentage set } & \multirow{2}{*}{ Total } \\
\hline & & \multicolumn{11}{|c|}{$0-3-6-10-15-20-30-40-50-60-70$} & \\
\hline 5021 & $\begin{array}{l}\text { Sa. } x \\
\text { Sa. } y\end{array}$ & $\begin{array}{l}22 \\
39\end{array}$ & $\begin{array}{l}2 \\
4\end{array}$ & $\begin{array}{l}0 \\
2\end{array}$ & $\begin{array}{l}I \\
4\end{array}$ & I & $\begin{array}{l}0 \\
0\end{array}$ & $\begin{array}{l}0 \\
0\end{array}$ & $\begin{array}{l}0 \\
0\end{array}$ & $\begin{array}{l}0 \\
0\end{array}$ & $\begin{array}{l}0 \\
0\end{array}$ & $\begin{array}{l}\text { o } \\
\text { I ? }\end{array}$ & $\begin{array}{l}26 \\
5 \mathrm{I}\end{array}$ \\
\hline $509 x$ & $\begin{array}{l}\text { Sa. } x \\
\text { Sa. } y\end{array}$ & $\begin{array}{l}52 \\
29\end{array}$ & $\begin{array}{l}0 \\
\text { I }\end{array}$ & $\begin{array}{l}\circ \\
0\end{array}$ & $\begin{array}{l}0 \\
0\end{array}$ & $\begin{array}{l}0 \\
0\end{array}$ & $\begin{array}{l}0 \\
0\end{array}$ & $\begin{array}{l}0 \\
0\end{array}$ & $\begin{array}{l}0 \\
0\end{array}$ & $\begin{array}{l}0 \\
0\end{array}$ & $\begin{array}{l}0 \\
0\end{array}$ & $\begin{array}{l}0 \\
0\end{array}$ & $\begin{array}{l}52 \\
3^{2}\end{array}$ \\
\hline $5 \mathrm{IO}_{1}$ & $\begin{array}{l}\text { Sa. } x \\
\text { Sa. } y\end{array}$ & $\begin{array}{l}23 \\
23\end{array}$ & $\begin{array}{l}5 \\
2\end{array}$ & $\begin{array}{l}3 \\
1\end{array}$ & $\begin{array}{l}4 \\
1\end{array}$ & $\begin{array}{l}5 \\
5\end{array}$ & $\begin{array}{l}2 \\
0\end{array}$ & $\begin{array}{l}2 \\
0\end{array}$ & $\begin{array}{l}\text { I } \\
\text { o }\end{array}$ & I & $\begin{array}{l}0 \\
0\end{array}$ & $\begin{array}{l}\mathbf{0} \\
\text { o }\end{array}$ & $\begin{array}{l}46 \\
33\end{array}$ \\
\hline
\end{tabular}

From table 10 it is clear that these three families segregated according to expectation into two intra-sterile, inter-fertile groups. The separation of crosses into compatible and incompatible presented but little difficulty, as can be seen from the frequency of pseudocompatibility in table II. This latter table gives an indication of the spread of seed-setting that can be expected when plants of similar genotypes, which express only a small degree of pseudo-compatibility, are intercrossed. It will be recalled that the gene Sa showed slight pseudo-compatibility when present in the homozygous genotype- 
Sa. $a$-and it appears from the similarity in the degree of pseudocompatibility in the above families as compared with the Sa. $a$ crosses, previously reported, that the seed-set shown in table I I might have been due to the $\mathrm{Sa}$ allele. If that is so, it is important to note that the inhibitory powers of $\mathrm{Sa}$ have been affected more by genetic recombination in family $5 \mathrm{IO}_{1}$ than in either of the other two where it has remained practically unchanged.

\section{(e) The number of allelomorphs governing compatibility}

The first experiment designed to indicate the number of incompatibility factors in natural populations was conducted with 22 plants drawn at random from two different populations of alsike. These were crossed as females with $\mathrm{La} / 87 / \mathrm{I}, \mathrm{La} / 77 / \mathrm{I}$ and $\mathrm{La} / 77 / 6$. The male parents have already been shown to be of the constitution Sc. $c$, Sa. $a$ and Sa. $a$ respectively. The populations from which the female parents were taken were in all probability large breeding populations such as would be expected in commercial seed production stands. It is not known what inter-relationships, if any, existed between these two populations.

A total of sixty-five crosses were completed, and, apart from one cross which proved to be sterile, seed-setting was normal for compatible crosses. The one sterile cross of the series $(92 / 8 \quad 0 \times \mathrm{La} / 77 / 1$ of) was obviously accidental because, when the same female parent was crossed with the other Sa. $a$ tester-La/77/6-full compatibility resulted. This result indicates that neither the Sc nor the Sa alleles occur among the $44 \mathrm{~S}$ alleles present in this material, and that the allelic series is extensive. Using a method suggested by Stevens (1942), on the basis of the observed frequency, the upper limit of the frequency of both of these alleles is 9.90 per cent. at the I per cent. level.

Another test on the number of alleles governing incompatibility in this species was made on progeny derived from crossing I I randomly selected plants with a homozygous male-La/77/6 (Sa. a). From these matings, I I $\mathbf{F}_{\mathbf{1}}$ families were raised, and, according to expectation, each family should consist of two sterility groups. Each of the two groups should have one allele- $\mathrm{Sa}$-in common, as well as one unidentified allele from the female parent. The first step in the identification of the 22 alleles from the I I female parents consisted of separating 6 sibs from each family into the two genotypes; this was accomplished by using one sib from each family as male tester on the other five. Twenty-two plants - two from each $F_{1}$ familywere thus selected, and, in order to check the presence of Sa in each, they were back-crossed in both directions to the homozygous parent. The results of these crosses demonstrated the presence of $\mathrm{Sa}$ in each of the selections. The unidentified alleles were then tested by intercrossing the 22 selected plants. These crosses were performed in only one direction. 
Out of a total of 23 I matings, only i I proved to be incompatible. The incompatible crosses were :-
우 0
(I) $507_{1} x \times 5041^{*} *$
(2) $508_{1} y \times 508_{1} x$
(7) $\begin{gathered}\text { 은 } \\ 5 \mathrm{Io}_{1} y \times 507, y\end{gathered}$
(3) $50_{1} x \times 506_{1} y$
(8) $5 \operatorname{I2}_{1} y \times 506{ }_{1} x$
(4) $5_{0} y \times 5031_{1} x$
(9) $5^{\mathrm{I}} 31_{1} x \times 5{ }^{\circ} 5_{1} x$
(5) $5 \mathrm{Io}_{1} x \times 506_{1} y$
(6) $5 \mathrm{IO}_{1} x \times 5 \operatorname{Oog}_{1} x$
(IO) $5 \mathrm{I}_{31} y \times 508_{1} x$
(I I) $5 \mathrm{I} 31 v \times 508, y$

* $x$ and $y$ refer to the two unidentified alleles in each of the $x$ f families.

The above incompatible crosses were repeated in both directions, and from a total of 5284 florets pollinated, the seed-set was only I 65 per cent. It will be noted from the above that $508_{1} x$ and $508_{1} y$ were incompatible with each other, and that therefore only one of the two genotypes had been extracted from family $508_{1}$. This error undoubtedly arose because of the pseudo-self-compatibility exhibited by $508_{1} y$, which, on the basis of early examination of the pods, suggested compatibility with the tester plant.

From these results one can conclude that of the 2 I alleles tested, I 3 were different, 6 were represented twice, and I three times. In the sample tested, the number of unlike alleles amounted to 62 per cent. of the total.

Bateman (1947), following a method suggested by Stevens (1942) for calculating tests of significance on mutation rates, determined the number of alleles operating in population samples of red clover described by R. D. Williams and W. Williams (1947a). The calculation is based on the assumption that all the alleles are of equal frequency, but since this is very unlikely, the method can only be regarded as a very rough estimate. Further, Fisher (1947) showed that the upper limits of variation in such data is not reliable and therefore should not be used.

The application of the method to the present results gives a total number of alleles of 22 within the limits of 10 and 65 ? at the I per cent. point. (The probability of finding an allele common to a pair of plants was taken as $\frac{4}{n+\mathrm{I}}$.) The total number of alleles suggested by the above data is considerably less than in red clover, where the number calculated was 212. Owing to the large errors of sampling that must inevitably be involved in such tests, it is not possible to make a reliable comparison between the species in this respect.

\section{THE EVOLUTION OF INCOMPATIBILITY}

The number of species possessing an oppositional factor control over the sterility mechanism is gradually being shown to comprise many varied classes of plants; the majority are insect-pollinated. 
It appears, in view of the number of families which are known to contain this type of sterility mechanism, that similar evolutionary trends have been happening independently in many different species.

The relationship between self-fertile and self-sterile types is important in connection with the development of a sterility mechanism. Although no direct evidence seems to be available on the evolutionary positions of these two groups, one is able to form a justifiable opinion when the fertility mechanism is considered in relation to life cycle.

The first reference known to the writer where a correlation was shown between life cycle and fertility is that of Kirchner (1905). In all, 36 genera comprising 94 different species were listed from the Leguminosæ, and of the $5 \mathrm{I}$ annual species 45 were definitely selffertile, while among the 44 biennial or perennial species only 4 were self-fertile-4o being self-sterile. One of the species, Medicago lupulina, possessed two forms-an annual and a perennial form. The annual type was found to be self-fertile, while the perennial was self-sterile. Kirchner further analysed a list of self-fertile and self-sterile plants given by Darwin $(1876)$ and found a strong association between the type of life-cycle and fertility. This latter list consisted of ro8 species drawn from a variety of genera. Williams (I93 Ia) found in his tests with twenty different Trifolium species that only one-Trifolium fragiferum, which is a self-fertile perennial-failed to show the type of correlation suggested by Kirchner. The conclusions drawn by Williams appear to have been independent of Kirchner's observations. Further, Beddows (I93I) showed that of 35 annual gramineous species studied, only 5 could be classified as self-sterile. Twenty out of 29 perennial species, on the other hand, failed completely to set seed with their own pollen. The association observed by Kirchner in the leguminosæ seems therefore to hold in other families as well, including the wide range of families and genera given in Darwin's list.

From extensive cytological evidence, Müntzing (1936), Tischler (1937), Senn (1938), and Stebbins (1938) concluded that, in general, perennial forms have arisen from annuals by polyploidy, and that consequently the annual forms are probably in the majority of instances the ancestral types. In view of the association which appears to be fairly general between the annual habit and self-fertility, it may be suggcsted that self-sterile perennial forms arose from more primitive self-fertile annual forms, and that the oppositional factor basis for the inheritance of sterility arose by mutation from plants which were self-fertile.

This was the conclusion arrived at by East (1929) on phylogenetic evidence. The development of the sterility alleles according to East would be possible, and any mutation would be preserved, through the self-fertility of the genotype containing the new mutant in a heterozygote (e.g. Sf. I). As the number of mutations increased, the survival of self-sterile genotypes would be ensured. Mather (1943) on the 
basis of specific crosses with Petunia spp. agrees that the incompatibility system arose from a self-compatible ancestor, but argues that it could not have developed in Petunia by direct mutation giving strong sterility alleles which persisted under cover of the Sf gene as suggested by East. This disagreement is based on two reasons. First of all, the mutant in Petunia would have been female sterile, because the selffertile allele $(\mathrm{Sa})$ found in $P$. axillaris was not able to traverse styles carrying the mutants $S_{1}$ or $S_{2}$, or both. In my opinion, however, the existence of only partial compatibility between $P$. axillaris and $P$. violacea may suggest that these two species have been isolated as breeding communities for some time, so that changes other than those directly concerned with the sterility alleles may have been responsible for the peculiar reaction of the self-fertile allele Sa. All the other self-fertile alleles discovered, for example in Nicotiana Langsdorffi (East, 1929), Trifolium pratense (Williams and Silow, 1933, and Williams and Williams, 1947), and Trifolium repens (Atwood, 1945), possessed none of the peculiarities shown by the self-fertile allele in Petunia axillaris. The substantiation of Mather's contention requires the demonstration of the behaviour of the $\mathrm{Sa}$ allele from $P$. axillaris in crosses with mutants that might arise within that same species.

The other point put forward by Mather in connection with the development of sterility alleles is that, on East's hypothesis, it is presumed that the mutants would spread through the population owing to the advantages of an outbreeding mechanism. This assumption he considered to be insecure because it necessitates that outbreeding superiority and mutation at the sterility locus should have occurred simultaneously in a population which had hitherto relied on an inbreeding mechanism. But, on the other hand, it is known that cross-fertilisation does occur occasionally under certain conditions even in typically self-fertilising species ( $c f$. wheat and oats), and that a considerable release of variability does occur when pure lines are crossed. Such species can therefore gain considerable advantage and flexibility from outcrossing through recombination and the segregation of extreme types, even though they are predominantly dependent on an inbreeding system; and in spite of the fact that no apparent development in the direction of outbreeding superiority has occurred.

\section{PSEUDO-COMPATIBILITY}

One of the most interesting aspects of the oppositional type of sterility shown by the present work on alsike is the expression of distinct levels of pseudo-compatibility by the different genotypes. It is not possible very often to know exactly the level of pseudo-compatibility existing in the other species reported in the literature, because many authors present their results in a form which does not involve setting out the actual seed-set obtained. 
Several conditions affecting pseudo-compatibility are known and have already been described. Foremost among these are (I) the stage of development of the head, and (2) the environmental conditions at the time of pollination. Emerson (1940) showed that if plants of Oenothera organensis were kept in the dark for a period of three days or more, the styles permitted a much longer growth of incompatible pollen-tubes than those kept in the light. The maximum effect was shown when the plants had been five days in darkness and when they were beginning to exhibit signs of general weakness owing to the absence of light. Plants in which only some branches were kept in the dark, and on which styles were tested, showed no increased growth of the pollen-tubes. Emerson concluded that the reason for the apparent weakening of the incompatibility reaction was due to the general state of physiological debility which is reached after the plant has been several days in the dark. The possibility of there being a diffusion of substances from the areas exposed to the light to those kept in the dark was not tested.

The relationship between pseudo-compatibility and the $\mathrm{S}$ alleles has been discussed by several authors. In Nicotiana, East (1929), while appreciating the likelihood of other genes behaving in such a way as to reduce further the inhibitory effect of some of the weaker alleles, concludes that "under comparable conditions each selfsterility gene possesses a characteristic pollen-tube growth-curve in incompatible matings." He further points out that in Nicotiana any subsidiary genes which may be responsible for accelerating pollentube growth express themselves only in the female, because intragroup matings exhibited differences in pseudo-compatibility in reciprocal crosses. East (1934) gives additional evidence to support his contention that other genes have little effect on the expression of pseudo-compatibility. Similar reactions were observed for incompatible pollen-tube growths involving similar $\mathrm{S}$ alleles, even though the sterility alleles were derived from different families which segregated for as many as six other genes. Atwood (1942) states that in Trifolium repens there is apparently little if any, relationship between $\mathrm{S}$ factors and the amount of pseudo-compatibility shown by the genotypes. The conclusion reached in this case was that pseudo-compatibility is governed in the species by the action of several additive genes. This data presented, however, are not conclusive as to whether individual $\mathbf{S}$ factors exhibit different levels of the incompatibility reactions.

Mather (1943) has suggested that the $\mathrm{S}$ locus is under the control of balanced combinations of polygenes which are capable of expressing any strength of reaction according to the particular combinations present. As soon as the balance of polygenes is upset, it is suggested, on the basis of the Petunia species-crosses, that the $\mathrm{S}$ factors cease to control the incompatibility reaction and lose their oppositional effect. A somewhat similar viewpoint has been adopted by Lewis (I943).

The pseudo-compatibility shown by different sterility groups in 
this investigation (for example, family I I $_{1}$ ) suggests that the incompatibility factors do play a part in determining the pseudo-compatibility reaction. If several independent genes were responsible for the expression of pseudo-compatibility in this family, one would expect all four sterility genotypes to show equal variation in seed-setting in pseudo-compatible crosses. Further, with one exception, all the homozygous plants $\mathrm{Sa}$. $a$ and Sc. $c$ showed that the control over the inhibitory reaction was very uniform in the different individuals of the same group, even though the families showed variations in pseudo-fertility. On the basis of several genes this would not be expected, unless certain of these $S$ alleles may have had such a dominating control over the reaction that the presence of modifiers would be rendered ineffective, while others with a weaker expression would respond immediately to the modifying genes.

In some instances it is possible that modifiers have been postulated to account for the natural variation in pseudo-compatibility that almost inevitably occurs in different tests. For instance, variations in seed-setting of as much as 14 and 80 per cent. have been found in the present tests even among different heads on the same plants which were selfed within a period of 30 minutes of each other. To distinguish this type of variation from that involving modifying factors requires several caref 1 lests in order to enable one to arrive at a true average for the plant. In view of this, the effect of modifiers postulated for certain species should be accepted only with caution.

In certain heterozygotes investigated in this material, the pseudofertility of one allele was shown to be considerably affected by the presence of an other allelel in the female parent. The only instance where a similar type of interaction has been reported is in Nicotiana (East, 1934) where it was found that the growth rate of the pollentubes carrying $\mathrm{S}_{1}, \mathrm{~S}_{4}$, or $\mathrm{S}_{5}$ alleles was faster when combined in a heterozygote with $S_{2}$ than when present as homozygotes. Such an interaction may be the effect of competition for a basic precursory compound necesary for the synthesis of the final inhibitory substances. This was suggested by Lewis (1943 and 1947) in connection with the interaction of $\mathrm{S}$ genes in diploid pollen grains of polyploid Oenothera organensis material. The evidence of intra- and inter-group crosses in alsike, together with the fact that no homozygotes (S.b. $b$ and Sd. $d$ ) appeared on selfing the original parents, suggest that the allele causing the interaction was relatively strong in its inhibitory reaction.

Note.-The behaviour of plant No. 6 in family $\mathrm{La} / 8_{7}$ cannot be adequately explained on the basis of results so far obtained. The following possibilities may be briefly mentioned :-

(1) The high pseudo-compatibility shown may have been brought about by a spontaneous mutation either at the $\mathrm{S}$ locus itself, or else in a locus directly modifying its expression of pseudo-compatibility. If a mutation happened at the $\mathrm{S}$ locus, this implies that a mutation can alter the pseudo-compatibility of Sc without enabling the mutant to become fully compatible with its parental allele. A mutation 
affecting the action of an S gene when present in the pollen in Oenothera organensis has recently been reported by Lewis (1946). The same mutation when occurring in the style behaved like the parent allele.

(2) The plant may have accumulated a large dose of positive modifiers, or else the balanced combinations of modifiers might have been so upset as to weaken the action of the $\mathrm{S}$ allele. The main objection to this lies in the fact that the change from no pseudo-compatibility in the three sister plants of the same constitution to approximately roo per cent. seed-setting by pseudo-compatibility in plant No. 6 shows greater discontinuity than would be expected on the basis of modifier action.

(3) The Sc locus might possibly have exchanged a part of its composition, for example a side-chain of the gene molecule, with a similar part of the $\mathrm{Sd}$ locus with which it was associated in the parent. It will be recalled that the Sc. $c$ genotype of plant No. 6 had the same pseudo-compatibility level as the Sc. $d$ plants, and that it was fully compatible when Sc. $d$ plants were used as males. The possibility of a cross-over must be borne in mind, particularly since the likelihood of an exchange within a compound locus in Gossypium has been discussed by Silow and Yu (1942).

\section{SUMMARY}

I. Trifolium hybridum proved to be highly self-sterile, and crosscompatibility has been shown to be of the diploid "oppositional factor" type first described in Nicotiana.

2. Pseudo-compatibility in the species has been found to vary considerably even among plants of the same family, and types approaching full self-fertility appeared among the different progenies studied.

3. In most of the progenies studied the expression of pseudocompatibility was shown to be under the direct control of the $\mathrm{S}$ genes.

4. The interaction of two different $S$ factors in the style had a pronounced effect on the level of pseudo-compatibility of certain alleles.

5. An Sc. $c$ plant was isolated in which the level of pseudocompatibility had been altered, either as a result of a mutation of $\mathrm{Sc}$ or else following a cross-over within the $\mathrm{S}$ locus. The change in Sc did not enable it to become fully compatible with the normal Sc allele.

6. Various tests have shown that the number of sterility alleles in alsike is extensive. Out of 2 I alleles studied, I 3 were shown to be different, 6 being represented twice, and I three times.

7. A marked correlation appears to exist between the life-cycle of plants and their breeding systems. It is suggested that incompatibility systems have arisen by mutation from self-fertile annual forms.

Acknowledgments.-I am deeply indebted to Professor T. J. Jenkin, Director of the Welsh Plant Breeding Station, for facilities to carry out this work, and for invaluable criticism and suggestions in connection with the investigations. I should also like to acknowledge the assistance I have had during the pollination seasons from various members of the Station's staff and from student assistants. 


\section{REFERENCES}

ATWOOD, s. S. 1942. Genetics of pseudo-self-compatibility and its relation to cross-compatibility in Trifolium repens. 3. Agric. Res., $64,699$.

ATwOOD, s. s. 1944. Oppositional alleles in natural populations of Trifolium repens. Genetics, 29, 428.

ATwOOD, s. s. 1945. The behaviour of the self-compatibility factor and its relation to breeding methods. F. Amer. Soc. Agron., 37, 99 I.

BATEMAN, A. J. 1947. Number of S-Alleles in a population. Nature, I60, 337.

BEDDows, A. R. 1931. Seed-setting and flowering in various grasses. Welsh Plant Breeding Station, Ser. H, 12, 5 .

DARWIN, ChARLEs. 1876. The Effects of cross- and Self-Fertilisation in the Vegetable Kingdom. London: Murray.

EAST, E. M. 1929. Self-sterility. Bibliog. Genet., 5, 331 .

EAST, E. M. I934. Norms of pollen-tube growth in incompatible matings of selfsterile plants. P.N.A.S., 20, 225.

EAST, E. M., AND MANGELSDORF, A. J. 1925. A new interpretation of the hereditary behaviour of self-sterile plants. P.N.A.S., II, 166 .

EAST, E. M., AND YARNELL, s. H. 1929. Studies on self-fertility. VIII. Self-sterility allelomorphs. Genetics, 14, 455 .

EMERSON, s. 1939. A preliminary report of the Oenothera organensis population. Genetics, 24, 524.

EMERSON, s. 1940. Growth of incompatible pollen-tubes in Oenothera organensis. Bot. Gaz., IOI, 890 .

FISHER, R. A. 1947. Number of self-sterility alleles. Nature, $160,797$.

FRUWIRTH, G. 1906. Die Züchtung der Landwirtschaftlichen Kulturpflanzen III. Bastardklee (Trifolium hybridum L.). Berlin, p. 185.

GRUBER, F. 1932. Über die Verträglichkeitsverhältnisse bei einigen selbststerilen Wildsippen von Antirrhinum und über eine selbstfertile mutante. Z.I.A.V., 62,429 .

JØRGENSEN, c. O. I92I. Om Bestøvnings-og Befrugtningsforhold hos nogle Graesmarksbaelgplanter med Henlbik paa deres Foraedling. (On the pollination and fertilisation of some pasture Leguminosae with a view to their improvement.) Kong. Vet. Landbohojskoles Aarsskrift, p. 218.

KIRGHNer, O. 1905. Über die Wirkung der Selbstbestäubung bei den Papilionaceen. Naturw. Zeitschr. Land-Forstwirtschaft, 3, 97.

LEHMann, E. 1926. The heredity of self-sterility in Veronica syriaca. Mem. Hort. Soc., N.Y., 3, 313 .

LEWIS, D. I943. Physiology of incompatibility in plants. III. Autopolyploidy. F. Genet., 45, I71.

LEWIS, D. 1946. Useful X-ray mutations in plants. Nature, $158,519$.

LEWIS, D. 1947. Competition and dominance of incompatibility alleles in diploid pollen. Heredity, $I, 85$.

Mather, k. 1943. Specific differences in Petunia. I. Incompatibility. F. Genet. $45,215$.

MEEHAN, T. 1892. Contributions to the life histories of plants. No. 8. P.N.A.S., p. 366 .

MÜNTzING, A. 1936. The evolutionary significance of autopolyploidy. Heriditas, 21,263 .

NILSSON-LEISSNER, G. I934. Sjävlfertilitetsundersökningar hos vit-och alsikeklöver. Nordisk Fordbrugsforskning, ${ }_{1} 6, \mathrm{I} 68$.

OWEN, F. 1942. Inheritance of cross- and self-sterility and self-fertility in Beta vulgaris. F. Agric. Res., $64,679$.

SENN, H. A. 1938. Chromosome number relationships in the Leguminosae. Bibliog. Genet., 12,175 . 
sllow, R. A., AND YU, C. P. 1942. Anthocyanin patterns in Asiatic cottons. 7 . Genet., 43, 249.

STEBbins, G. L. 1938. Cytological characteristics associated with different growth habits in the Dicotyledons. Amer: 7. Bot., 25, 189.

Stevens, w. L. 1942. Accuracy of mutation rates. F. Genet., 43, 30 r.

TISCHLER, G. 1937. On some problems of cytotaxonomy and cytoecology. Indian Bot. Soc. Fourn., 16,165 .

williams, R. D. I93 I $a$. Fertility of various herbage Legumes. Welsh Plant Breeding Station, Ser. H., 12, $22 \mathrm{I}$.

Williams, R. D. I93 1 . Methods and technique of breeding red clover, white clover and lucerne. Imp. Bur. Plant Genetics: Herbage Plants, Bull. 3.

WiLliams, R. D. 1939. Incompatibility alleles in Trifolium pratense L., their frequency and linkage relationships. P. Int. Gen. C. (7), p. 3 r6.

Williams, R. D., AND silow, R. A. 1933. Genetics of red clover (Trifolium pratense L.). Compatibility. I. F. Genet., 27, 34I.

Williams, R. D., AND Williams, w. 1947. Genetics of red clover (Trifolium pratense L.). Compatibility. II. (a) Homozygous self-sterile $\mathrm{SxSx}$ genotypes obtained as a result of pseudo-fertility, $(b)$ Self-fertility. 7 . Genet., $48,5 \mathrm{I}$.

Williams, R. D., AND williams, w. 1947a. Genetics of red clover (Trifolium pratense L.). Compatibility. III. The frequency of incompatibility $\mathrm{S}$ alleles in two non-pedigree populations of red clover. 7. Genet., 48,69 .

WITTE, H. I 908 . Ârsberättels eöver Sveriges Utsädesförenings verksamhet under ar 1907. Vallbaljväter. Sver. Utsädesfor. Tidskr., $18,148$.

zHELNiNA, A. v. 1932. On the methodics of breeding alsike clover. (In Russian with English summary.) Bull. App. Bot. Genet. Plant Breeding, No. 2, p. 63. 